Mateusz Rafal Potoczny

Wydział Teologiczny, UO

\title{
Wspólne DNA liturgii Wschodu i Zachodu
}

Zadaniem, jakie wynika z postawionego w tytule problemu, jest wskazanie wspólnego wszystkim tradycjom liturgicznym Kościoła kodu genetycznego, na podstawie którego możemy zweryfikować, która tradycja liturgiczna jest autentyczna, tzn. która dzieli z innymi dziedzictwo otrzymane od samego Chrystusa poprzez działalność Apostołów i ich następców. Owo DNA na płaszczyźnie liturgii możemy określić mianem „katolickości” w sensie takim, w jakim była ona rozumiana w Kościele pierwotnym i w nicejsko-konstantynopolitańskim Credo: słowo „katolicki”, oprócz tego, że znaczyło „powszechny” był właściwie terminem odróżniającym od tego, co związane było z sektami, a więc katolicki to nic innego jak ortodoksyjny, posiadający prawdziwy genotyp chrześcijaństwa ${ }^{1}$.

By odkryć ten wspólny genotyp liturgii, należy wpierw krótko scharakteryzować status quaestionis problemu we współczesnej myśli liturgicznej. Następnie trzeba sprecyzować, co rozumiemy pod pojęciem wspólnego genotypu, wydzielić kolejne partie tej kościelnej rzeczywistości i poddać je krytycznej analizie. Wydaje się, że taki proces badawczy będzie w stanie ukazać tę część wspólną, kręgosłup, na którym zrodziła się chrześcijańska pojednana różnorodność.

\section{Status quaestionis}

Kod DNA jest czymś, co definiuje wszystkie żywe organizmy. Obrazowo mówiąc; jest to struktura zbudowana z sekwencji czterech komponentów, które z kolei tworzą geny. I chociaż w przypadku organizmu ludzkiego rzeczonych komponentów jest ok. 3 miliardów i tworzą one 21000 genów, to większość z nich $(99,9 \%)$

${ }^{1}$ Por. J.H. SRawley (red.), The Epistles of St. Ignatius Bishop of Antioch, Brighton 1910, s. 41-42. 
jest wspólnych nam wszystkim. To co czyni z nas byty jednostkowe i niepowtarzalne zawiera się w tym małym ułamku procenta ${ }^{2}$.

Ponieważ Kościół wraz ze swoją liturgią określany bywa - i rzeczywiście jest - żywym organizmem (por. Rz 12,4-5), wydaje się, że podobne odniesienie genetyczne śmiało możemy odnieść również do liturgii. Nie chcę przesądzać, ile procent całego dziedzictwa stanowią tu elementy wspólne, a ile indywidualne elementy wypracowane przez poszczególne tradycje: wydaje się jednak, że może to być kalkulacja całkiem podobna do tej określającej gatunek człowieka.

I chociaż wspólny genotyp, wspólne dziedzictwo w żywych organizmach zdecydowanie przeważa, to jednak o wiele łatwiej mówić o tym, co je różni. Tak jest w przypadku ludzi, których rozróżniamy najpierw przez kolor skóry, rysy twarzy, włosy, zachowanie, etc., i tak jest w liturgii, gdzie na pierwszy plan wysuwają się rodziny liturgiczne, pobożność, stroje, tradycje lokalne, etc. .

Dlatego też, chociaż treścią niniejszego przedłożenia ma być wspólne DNA liturgii całego Kościoła, zwrócenie uwagi na elementy różniące może być dobrym punktem wyjścia - swoistą dedukcyjną wędrówką ku wspólnocie, podjętą jednak poprzez drogę eliminacji elementów oddzielających. Taki punkt wyjścia wydaje się uzasadniony również poprzez spojrzenia pragmatyczne: gdy mówimy o liturgiach Wschodu i Zachodu, często bardziej lub mniej świadomie przemycamy ideologię podkreślająca praestantia ritus latini, co w przeszłości, a niejednokrotnie także dzisiaj, kategoryzuje obrządki wschodnie jako byty tolerowane, aczkolwiek należące do drugiej kategorii ${ }^{3}$. I mimo tego, że idea zawarta w tym łacińskim postulacie nie była oczywistością w pierwszym tysiącleciu chrześcijaństwa, do dziś bywa zakorzeniona w świadomości wielu chrześcijan i miłośników liturgii rzymskiej, którzy chcieliby widzieć w niej jedyną normam normans, pomijając de facto współczesne nauczanie Kościoła bazujące na postulatach Soboru Watykańskiego II $^{4}$. Ów Sobór bowiem dał nowy impuls w kierunku zainteresowania się Kościołami chrześcijańskiego Wschodu oraz dowartościowania dziedzictwa - także liturgicznego - jakie Orient wnosi w całościowo pojęte chrześcijaństwo ${ }^{5}$. W związku z tym w drugiej połowie XX w. status quaestionis znacząco się zmienił. W encyklice Ut unum sint papież Jan Paweł II zwrócił uwagę na zauważalne zbieżności, jakie w dziedzinie

2 Zob. Genetic Science Learning Center, What are DNA and Genes?, http://learn.genetics.utah. edu/content/ basics/dna (29.10.2017).

${ }^{3}$ Por. E.G. Farrugia, Praestantia ritus latini, w: tenże (red.), Dizionario enciclopedico dell'Oriente Cristiano, Roma 2000, s. 611-612 (dalej: DEOC).

${ }^{4}$ Por. SobóR WATYKaŃSKI II, Dekret o kościołach wschodnich katolickich „Orientalium Ecclesiarum", nr 1.

5 Por. J.M. Czerski, Liturgie Kościołów Wschodnich, Opole 2009, s. 16. 
kultu stają się pomostem łączącym Kościoły Wschodu i Zachodu, przyznając refleksji nad liturgią ważne miejsce w dialogu ekumenicznym ${ }^{6}$. Również posoborowe podręczniki do liturgiki śmielej i odważniej nawiązują do prezentacji liturgii orientalnych, jednak i tu w dużej mierze uwypukla się różnice w liturgicznym genotypie Kościołów Wschodu i Zachodu.

Różnice, o których mowa, są wielopłaszczyznowe. Pierwsza grupa odnosi się do wspomnianych już wyżej tradycji liturgicznych związanych z konkretnymi ośrodkami. W klasyfikacji liturgii mówi się bowiem o liturgiach typu antiocheńskiego, aleksandryjskiego, o liturgii Kartaginy, Rzymu czy Konstantynopola. Wszystkie one w procesie kształtowania poddane były wielu czynnikom warunkującym ich przyszły kształt. Należały do nich elementy kulturowe, geograficzne, lingwistyczne, spory teologiczne oraz konkretna sytuacja polityczna. To wszystko wycisnęło na poszczególnych liturgiach charakter, czyniący z nich organizmy wyjątkowe i jednostkowe, wzajemnie od siebie różne ${ }^{7}$. Biorąc pod uwagę wymienione grupy czynników nie może nas dziwić, że Boska liturgia celebrowana w wywodzących się z ceremoniału dworskiego Kościołach bizantyjskich, bogata w śpiewy i ornamentykę cesarską, zdecydowanie różni się od prostej i pełnej cichego misterium liturgii koptyjskiej czy syro-orientalnej, która osiągnęła swój rozwój w kontekście społeczno-politycznym całkowicie nieprzyjaznym bądź - w najlepszym wypadku - cechującym się całkowitą obojętnością perskiej arystokracji ${ }^{8}$. Wskazując na pewne wymienione tu czynniki, zauważymy na przykład, że kwestia muzyki liturgicznej również rozwijała się inaczej w przestrzeni wpływów Rzymu, gdzie często była inspirowana i w pewien sposób moderowana przez różnego rodzaju mecenaty, inaczej zaś w kontekście wspólnot indyjskich chrześcijan św. Tomasza czy wiernych Kościoła etiopskiego, gdzie za jej rozwojem stała przede wszystkim lokalna pobożność ludowa.

Ponadto należy zauważyć, że niemal każda z liturgii Wschodu i Zachodu wypracowała własną dyscyplinę, która odnosi się do form celebracyjnych, sposobów uczestnictwa w liturgii, kwestii szafarstwa sakramentalnego czy też kalendarza liturgicznego. Jednakże mimo wielości różnic wciąż otwarte pozostaje pytanie: na ile determinują one genotyp poszczególnych liturgii? Czy poszukiwanie wspólnego DNA jest w ogóle badaniem zasadnym czy raczej ekscentryczną fanaberią, która nie niesie ze sobą istotnego przesłania? A może różne tradycje liturgiczne nie są jedynie lokalnymi akomodacjami jednej i tej samej liturgii?

${ }^{6}$ Por. Jan Pawee II, Ut unum sint, Città del Vaticano 1995, nr 44-45.

7 Szerzej zob. M. РотосzNy, Rodziny liturgiczne chrześcijańskiego Wschodu-panorama, „Teologia i człowiek" 25 (2014) 1, s. 165-185.

${ }^{8}$ Zob. W. Hage, Syriac Christianity in the East, Kottayam 1997, s. 1-13. 
Odpowiadając na te pytania, trzeba odnieść się do badań, wedle których istotne różnice liturgiczne nie są czymś, co cechowało pierwotne wspólnoty Kościoła od początku. Owszem, należy założyć, że w dobie tzw. improwizacji liturgicznej każdemu liturgowi pozostawiano dużą dozę wolności odnośnie do wypowiadanych słów i sprawowanych rytów ${ }^{9}$. Można powiedzieć, że był to przejaw prawdziwej katolickości, która w naturalny sposób odnajdywała właściwe sobie formy wyrazu w lokalnych zwyczajach i praktykach ${ }^{10}$. Jednakże w sprawach istotnych nie było różnic, a jeśli nawet takie się pojawiały, były one bezwzględnie tłumione. Jak zauważa Josef A. Jungmann, taka sytuacja trwała właściwie do IV w. i dopiero od tego czasu możemy wskazywać zasadnicze elementy różniące poszczególne liturgie Kościoła ${ }^{11}$. Zatem aby dotrzeć do wspólnego DNA liturgii Wschodu i Zachodu, trzeba nam sięgnąć najpierw do korzeni, a następnie w tej perspektywie ukazać współczesne praktyki liturgiczne i zweryfikować obecny w nich genotyp. Weryfikacja owego wspólnego DNA powinna dokonać się w dwóch wymiarach: chronologicznym oraz euchologijnym.

\section{Wspólne korzenie liturgii Wschodu i Zachodu}

Chronologiczne poszukiwanie wspólnego genotypu liturgii całego Kościoła każe nam sięgnąc do początków: nie tylko tych związanych z działalnością Kościoła pierwotnego czy nawet Apostołów oraz samego Jezusa Chrystusa. Wszak Kościół oraz jego liturgia nie zostały stworzone ex nihilo wraz z inkarnacją Słowa Bożego. Louis Bouyer, propagator zależności i genealogicznej ciągłości między liturgią żydowską a chrześcijańską zwykł mawiać, że tylko Melchizedek nie miał ojca i matki, natomiast chrześcijańska liturgia rodziców posiada ${ }^{12}$.

\subsection{Liturgia żydowska}

Jak zgodnie podkreślają badacze liturgii, pierwszym elementem, z którego należy wywodzić wspólne jej korzenie na Wschodzie i Zachodzie, jest liturgia judaistyczna, do której należał zarówno kult świątynny i synagogalny, jak i liturgia

9 Por. J.A. Jungmann, Liturgia Kościoła pierwotnego do czasów Grzegorza Wielkiego, thum. T. Lubowiecka, Tyniec 2013, s. 316.

${ }^{10}$ I.-H., Dalmais, Liturgies d'Orient. Rites et symboles, Paris 1980, s. 32.

${ }^{11}$ Por. J.A. Jungmann, Liturgia Kościoła pierwotnego, s. 316.

12 Zob. L. BOUYER, Eucaristia. Teologia e spiritualità della preghiera eucaristica, Leumann 1983, s. 27. Por. TenżE, Architettura e liturgia, Magnano 2007, s. 17. 
domowa ${ }^{13}$. Chociaż pierwotna wspólnota Kościoła od samego początku rozwijała się pod silnym wpływem greckiej myśli, kultury i języka, to jednak nie ulega wątpliwości, że jej korzenie wciąż mocno tkwiły w Starym Testamencie. Roger T. Beckwith zauważa, że chociaż nauczanie Jezusa Chrystusa cechowała niezwykła oryginalność, to jednak to wszystko, co dotyczyło w niej źródeł, odnosiło się do judaizmu. Ponadto fakt, że zarówno Jezus Chrystus, jak i jego uczniowie uczestniczyli w kulcie żydowskim i zasadniczo cenili jego praktyki, jest ważną wskazówką ukierunkowującą poszukiwania wspólnego i najbardziej pierwotnego genotypu liturgii Kościoła różnych tradycji ${ }^{14}$. Oczywiście, na przestrzeni wieków nie wszystkie interpretacje tego stanowiska były jednakowe. Nawet w najnowszych badaniach spotykamy cały ich wachlarz: od niezwykle entuzjastycznych, widzących w liturgii żydowskiej niemal pierwowzór całego kultu chrześcijańskiego, po całkowicie negujące jakiekolwiek znaczące wpływy kultu Izraela na chrześcijański wyraz liturgii ${ }^{15}$.

Wydaje się jednak, że tezy odrzucające wpływ kultu Starego Testamentu na pierwotną liturgię chrześcijańską są nie do obronienia. Wszak kultu Kościoła, który tak samo jak liturgia w Starym Testamencie jest odpowiedzią na Bożą inicjatywę zbawczego dialogu, nie można oderwać od całościowo pojętej ekonomii zbawienia. Poszczególne jej elementy nie są od siebie oderwane, ale stanowią kolejne ogniwa łańcucha wzajemnie zależnych elementów zbawczych ${ }^{16}$. A jeśli tak jest, to w DNA liturgii chrześcijańskiej musi znajdować się kod kultu Starego Przymierza. Oczywiście, jak podkreślił Josef Ratzinger, „liturgia wiary chrześcijańskiej nie może być uważana za schrystianizowaną formę kultu synagogi, jakkolwiek w swym konkretnym kształcie wiele zawdzięcza liturgii synagogi" ${ }^{17}$.

W podobnym kluczu wypowiada się Jungmann. Zauważając fakt, że sam Pan spełniał kult Starego Testamentu, dodaje, że czyniąc to Jezus jasno oznajmiał, że kult ten nie będzie dłużej obowiązywał, gdyż nowa liturgia ma być liturgią zupełnie innego rodzaju i innego ducha (por. J 4,23-24) ${ }^{18}$. W kulcie zaproponowanym i nadanym przez Syna Bożego liturgia nie jest już tylko sprawowaniem misteriów kultycznych, ale prawdziwą anamnezą, która interesując się przeszłością nie zatrzymuje się na

${ }^{13}$ Por. B. Nadolski, Wprowadzenie do liturgii, Kraków 2004, s. 33nn.

${ }^{14}$ R.T. Beckwith, The Jewish Background to Christian Worship, w: Ch. Jones I IN. (red.), The Study of Liturgy, New York 1992, s. 68.

15 Por. B. Nadolski, Wprowadzenie do liturgii, s. 35.

${ }^{16}$ Por. J.D. Crichton, A Theology of Worship, w: CH. Jones I In. (red.), The Study of Liturgy, s. 9-10.

17 J. Ratzinger, Duch liturgii, Poznań 2002, s. 45.

18 Por. J.A. Jungmann, Liturgia Kościoła pierwotnego, s. 28. 
niej, ale każe przeżywać ją tu i teraz. Ta prawda konkretyzuje się w ujęciu Sørena Kierkegaarda oraz Odo Casela, którzy podkreślali, że w liturgii chrześcijańskiej Chrystus staje się współczesny każdemu, kto w niej uczestniczy ${ }^{19}$.

Skoro więc kult Starego Testamentu, choć zdecydowanie różny od chrześcijańskiego, wywarł wpływ na liturgię Kościoła, jaką wartość należy mu nadać w ewolucji genotypu liturgii? W tym kontekście ciekawą interpretację podaje nam Michael Kunzler, wedle którego kult Starego Testamentu był tak na prawdę Vorliturgie (dosł. ,przedliturgią"), mającą przygotować liturgię prawdziwą ${ }^{20}$. Jako bezpośrednie przygotowanie byłby on więc pierwotnym materiałem genetycznym, czy - jak mówi Bogusław Nadolski - „matką ziemią”, z której dzięki dynamizmowi historii wyrastała liturgia chrześcijańska ${ }^{21}$.

Niezależnie od oceny stanowiska, które w poszukiwaniu wspólnego DNA liturgii Wschodu i Zachodu sięga do tradycji Izraela, należy zapytać: w czym ów żydowski kod genetyczny możemy odnaleźć? Autorzy podejmujący zagadnienie wskazują różne punkty styczne obu tradycji. Protestancki teolog Christian Grethelein jako elementy genetycznie związane z judaizmem i stąd wspólne liturgiom Wschodu i Zachodu wymienia:

- użycie psalmów w liturgii;

- święto Paschy;

- święto Przaśników;

- kult męczenników;

- rachuba dnia liturgicznego (wieczór - wieczór);

- aklamacje (alleluja, amen, hosanna);

- trzykrotny Sanctus oparty na wizji proroka Izajasza (Iz 6,3);

- tzw. paradygmat „,modlitwy o ratunek”;

- gest nałożenia rąk;

- orationes solemnes;

- układ modlitw Liturgii godzin;

- kończenie modlitwy doksologią;

- podobieństwa w wykonywaniu śpiewu;

- struktura roku liturgicznego ${ }^{22}$.

Z kolei Roger T. Beckwith podejmuje tę kwestię nieco bardziej szczegółowo i wskazuje na judaistyczne wpływy w następujących elementach liturgicznych: sa-

19 Zob. J.D. Crichton, A Theology of Worship, s. 14.

${ }^{20}$ Zob. M. Kunzler, Liturgia Kościoła, Poznań 1999, s. 73-78.

${ }^{21}$ Por. B. NAdolski, Wprowadzenie do liturgii, s. 36.

${ }^{22}$ Zestawienie za: tamże, s. 37. 
kramenty inicjacji chrześcijańskiej, obrzędy przedkomunijne i komunijne we Mszy świętej, oficjum codzienne, posługi i święcenia w Kościele oraz kalendarz liturgicz$n y^{23}$. Zaproponowane przez Beckwitha obszary stanowią wciąż otwarte pole badawcze. Niewątpliwie w wymienionych elementach istnieje szereg punktów stycznych judaizmu i chrześcijaństwa jednakże ich ostateczna ewaluacja wskazująca na niezaprzeczalnie wspólne DNA wymagałaby o wiele bardziej rzetelnego studium. Stąd na potrzeby niniejszego referatu bardziej konkretny katalog elementów liturgii autorstwa Gretheleina jawi się jako zupełnie wystarczający. Istotnie, wszystkie te elementy stanowią wspólne dziedzictwo całego Kościoła i na przestrzeni wieków pozostały integralnymi składowymi kultu bez względu na denominację eklezjalną wspólnot chrześcijańskich Wschodu i Zachodu zaliczanych do tzw. Kościołów Apostolskich. Mimo tego, że w różnych Kościołach różnie wyakcentowane zostały części składowe zaproponowanego katalogu, w jasny sposób tworzą one genetyczny łańcuch wiążący liturgie chrześcijańskie z ich żydowską kolebką. Oczywiście, na katalog ten składają się najbardziej widoczne elementy i z całą pewnością nie wyczerpuje on wszystkich cech odziedziczonych przez liturgię Kościoła. Można tu bowiem zaliczyć cały szereg wyrazów tzw. pobożności ludowej, nawiązującej również do praktyk starotestamentalnych, do których należą chociażby pielgrzymki. Z punktu widzenia liturgii chrześcijańskiej najważniejszym elementem bazującym na tradycji żydowskiej jest bez wątpienia celebrowana raz w roku wieczerza paschalna (seder hagada šel pesach), cotygodniowa wieczerza szabatowa (chaburah) oraz synagogalna modlitwa poranna (brachot) które bezpośrednio wpłynęły na kształt chrześcijańskiej liturgii eucharystycznej ${ }^{24}$.

\subsection{Gloszenie kerygmatu i życie sakramentalne}

Kolejnym wspólnym elementem liturgii Kościoła Wschodu i Zachodu jest głoszenie kerygmatu. Prawda o zmartwychwstaniu Jezusa Chrystusa oraz jej moralny i parenetyczny wymiar od samego początku stanowiły główny wyraz apostolskiej działalności Kościoła. I chociaż to głoszenie kerygmatu dokonywało się na różnych poziomach misji, z jaką uczniowie Jezusa Chrystusa szli do świata,

${ }^{23}$ Zob. R.T. BескwITH, The Jewish Background, s. 73-79.

${ }^{24}$ Por. H. PAProcki, Misterium Eucharystii, Kraków 2010, s. 13-17. J.A. Jungmann stoi na stanowisku, że apostołowie w praktyce liturgicznej nie mogli powtarzać posiłku paschalnego, gdyż był to ryt skomplikowany i nie nadawał się do częstego powtarzania. $Z$ resztą prawo żydowskie, którego przecież apostołowie ściśle przestrzegali, pozwalało na celebrację tego obrzędu jedynie raz w roku. Stąd, zdaniem autora, najbardziej prawdopodobnym ,prototypem” celebracji eucharystycznej jest znacznie prostsza w swej strukturze uczta szabatowa. Zob. J.A. Jungmann, Liturgia Kościoła pierwotnego, s. 57-58. 
to jednak uprzywilejowanym miejscem zwiastowania wynikających z wydarzenia Jezusa prawd wiary była liturgia. Oczywiste jest, że zanim ukształtował się kanon ksiąg natchnionych Nowego Testamentu, pierwsi świadkowie nie tylko korzystali z depozytu przekazanego przez tradycję żydowską, ale również w ramach zgromadzeń liturgicznych opowiadali o zbawczych wydarzeniach Jezusa Chrystusa. Podania biblijne i wczesne pisma patrystyczne jasno ukazują, że słowo Boże od samego początku było istotnym elementem wszelkich celebracji liturgicznych. Stąd bez jakiejkolwiek przesady można stwierdzić, że bez tegoż Słowa i jego proklamacji w ramach chrześcijańskich zgromadzeń kultycznych nie byłoby żadnej z liturgii ${ }^{25}$.

Świadomość doniosłości głoszenia kerygmatu i w ogóle proklamacji Słowa Bożego w ramach liturgii towarzyszyła chrześcijanom od samego początku. Benedykt XVI w adhortacji apostolskiej Verbum Domini zauważył, że „w czynności liturgicznej słowo Boże łączy się z wewnętrznym działaniem Ducha Świętego, który sprawia, że działa ono w sercu wiernych [...]; dzięki Parakletowi słowo Boże staje się fundamentem czynności liturgicznej, normą i wsparciem dla całego życia"²6.

Takie rozumienie Słowa Bożego wspólne jest właściwie wszystkim tradycjom liturgicznym Wschodu i Zachodu i w związku z tym jest ono par excellence nośnikiem genetycznego kodu liturgii całego Kościoła. Patrząc wstecz, należy uświadomić sobie, że na wszystkich szerokościach geograficznych, dokąd dotarło chrześcijaństwo starożytności, to właśnie fragmenty Biblii stanowiły tak naprawdę jedyną księgę liturgiczną przez pierwsze trzy wieki życia Kościoła. Rytm oddychania wspólnot dyktowany był duchem przekazywanym poprzez proklamację słowa, która była tak istotna, że - jak wiemy z podań patrystycznych - trwała tak długo, jak pozwalał na to przewodniczący liturgii ${ }^{27}$.

Jednakże wspólny kształt genetycznego kodu liturgii Wschodu i Zachodu nie ograniczał się jedynie do liturgii słowa obecnej w każdej celebracji sakramentalnej, ale w ogóle zauważalny jest w podejściu do celebracji misteriów chrześcijańskich, zwłaszcza związanych z wtajemniczeniem. Udzielanie chrztu świętego jako wyraz włączenia nowego członka do wspólnoty Kościoła od samego początku było dla chrześcijan oczywistą odpowiedzią na wezwanie Chrystusa: „Idźcie więc i nauczajcie wszystkie narody, udzielając im chrztu w imię Ojca i Syna, i Ducha Świę-

${ }_{25}$ M. Ротоczny, Słowo Boże w liturgii eucharystycznej Kościołów syryjskich, „Studia Liturgiczne" 13 (2017), s. 155.

${ }^{26}$ Benedykt XVI, Verbum Domini, Città del Vaticano 2010, nr 52.

27 Zob. M. Ротосzny, Stowo Boże, s. 158. 
tego" (Mt 28,19). Z przekazów biblijnych wiemy, że ten nakaz Pana Jezusa uczniowie realizowali niemal natychmiast po wydarzeniach paschalnych, a jego przyjęcie było warunkiem sine qua non otwarcia nowemu uczniowi Chrystusa bram wiary (por. Dz 8,25-39) ${ }^{28}$. Ponadto, również od samego początku, istotową częścią liturgii Kościoła była celebracja Eucharystii, która nazywana była „łamaniem chleba” (por. Dz 2,42). Ponieważ w dalszej części niniejszego studium bliżej zajmiemy się tą kwestią, zaznaczmy jedynie, że zarówno rozumienie tajemnicy przekazywanej w celebracji liturgii eucharystycznej jak i oczyszczeniowo-inicjacyjna funkcja chrztu św. były wspólnymi elementami całego Kościoła i bez wątpienia należą do podstawowej struktury genetycznej liturgii wszystkich obrządków.

\subsection{Wspólna geografia początków}

Poszukując wspólnego DNA liturgii Wschodu i Zachodu należy choć pokrótce odwołać się do oczywistego, aczkolwiek nie zawsze docenianego faktora, jakim jest geografia. Chociaż jest to najbardziej zewnętrzny ze wszystkich elementów badawczych, to jednak i tu możemy dotrzeć do pierwotnego genotypu chrześcijańskiej liturgii.

Jak zaznaczono powyżej, tym co pozornie wskazuje na istotę liturgii każdego Kościoła, są elementy odróżniające jedną tradycję liturgiczną od drugiej. Taki punkt wyjścia często odnosi się także do kwestii geograficznych. Na przestrzeni wieków to właśnie geografia często determinowała ortodoksyjność rytu. Należy założyć, że właściwie od czasu usankcjonowanej przez Sobór w Chalcedonie (451 r.) pentarchii coraz bardziej polaryzowało się rozumienie tego co prawdziwe, autentyczne i miarodajne w niemal każdej przestrzeni życia kościelnego, także w liturgii. Późniejsza historia potwierdza, że normą życia liturgicznego na obszarze wpływów danego patriarchatu była liturgia stolicy patriarszej. Stąd dla wiernych Kościoła Rzymu najprawdziwszą liturgią była liturgia rzymska, w Aleksandrii aleksandryjska, a w Antiochii - antiocheńska. Takie rozumienie nie musi z założenia być błędne, ale niesie ze sobą ryzyko popadnięcia w niezdrowy partykularyzm, pomijający to, co w istocie powinno być wyrazem katolickości, czyli genetyczne dziedzictwo liturgii.

Philippe Jenkins zauważył, że nasze zachodnie myślenie na temat rozwoju chrześcijaństwa koncentruje się na Europie i basenie Morza Śródziemnego, za czym stoi przekonanie, że to właśnie ten obszar był sceną najintensywniejszej

28 TenżE, Praxis $i$ teologia chrztu $w$ liturgicznej tradycji syro-orientalnej, „Studia Łódzkie” 26 (2017) 2, s. 136. Por. M. Righetti, Storia liturgica, v. 4, I sacramenti - i sacramentali, Milano 2014, s. 28 
i najważniejszej aktywności misyjnej pierwotnego Kościoła. W ten sposób pomijamy albo - w najlepszym razie - marginalizujemy tę przestrzeń, która dla genezy chrześcijaństwa i jego liturgii była najbardziej pierwotna ${ }^{29}$. Jerozolima, bo o niej tu mowa, jest przecież naturalnym geograficznym nośnikiem poszukiwanego przez nas DNA chrześcijańskiego kultu. Tę prawdę intuicyjnie wyczuwali średniowieczni autorzy symbolicznych map świata, którzy bardzo często właśnie w centrum stawiali to święte miasto ${ }^{30}$.

Geograficzne DNA liturgii widziane w tym właśnie kluczu stoi blisko omawianej już liturgii żydowskiej, jednak jest od niej o wiele szersze. Zawiera bowiem w sobie całą nowość chrześcijaństwa zogniskowanego wokół miejsc, w których dokonywały się istotne wydarzenia związane z działalnością Jezusa Chrystusa i pierwszego pokolenia Jego uczniów. Wszyscy oni byli przecież dziećmi swoich czasów i swojej kultury, która była kulturą zhellenizowaną, ale jednak semicką. Do dziś najwięcej elementów wynikających z tego geograficznego faktora odnajdujemy w liturgiach Kościołów syryjskich, które są dziedzicami w linii prostej pierwotnego semickiego chrześcijaństwa i do dziś zachowały jako liturgiczny język syryjski, będący dialektem aramejskiego oraz liczne zwyczaje żydowskie $^{31}$. Jednakże również $w$ innych tradycjach liturgicznych odnajdujemy szereg elementów kulturowych, które przeszły do nich z geograficzno-kulturowego obszaru Palestyny. Wśród nich z całą pewnością możemy wymienić symbolikę liturgiczną. Wszak duża ilość znaków i symboli liturgicznych przeszła do naszych liturgii właśnie ze świata semickiego, opisanego na kartach Starego Testamentu. Aimé G. Martimort wymienia ich cały szereg. Pisze na przykład, że już samo rozumienie sakramentów jest podobne do rozumienia znaków biblijnych Starego Przymierza, które oznaczały łaskę, jaką ze sobą niosły. Woda chrztu nie jest tylko wodą, która oczyszcza; Eucharystia nie jest zwyczajnym posiłkiem, ale pokarmem historycznym; namaszczenie chrzcielne może być zrozumiane, tylko jeśli patrzymy na nie jak na starotestamentalną konsekrację królów lub kapłanów. Autor dodaje, że gdy na modlitwie czynimy gesty i uczestniczymy w akcji liturgicznej, powtarzamy je za tymi wszystkimi, którzy czynili je przed nami, sięgając wstecz do Abrahama, gdyż wynika to z całej historii zbawienia ${ }^{32}$. Do tych znaków z całą pewnością możemy dołączyć symbolikę baranka czy znak

29 P. Jenkins, The Lost History of Christianity, New York 2008, s. 21.

${ }^{30}$ Zob. tamże, s. 23.

${ }^{31}$ Por. S. Brock, The Holy Spirit in the Syrian Baptismal Tradition, Kottayam 1998, s. 1.

32 Zob. A.G. MARtimort, Struttura e leggi della celebrazione liturgica, w: teNŻe (red.), La Chiesa in preghiera. Introduzione alla Liturgia, Brescia 2009, s. 199. 
niekwaszonego chleba, który - choć nie we wszystkich Kościołach przyjęty został dla sprawowania liturgii eucharystycznej - prowokował w historii dyskusje teologiczne, stając się tym samym elementem wskazującym na wspólny genotyp liturgii ${ }^{33}$.

\section{Euchologia nośnikiem wspólnego DNA liturgii}

Do tego momentu w niniejszym studium wspólne DNA liturgii Wschodu i Zachodu odkrywane było w obiektywnych elementach stojących niejako na zewnątrz celebracji. Jednakże wspólny genotyp - jeśli rzeczywiście taki istnieje - powinien istnieć również w najintymniejszej strukturze liturgii. Wydaje się, że nasze badanie byłoby niepełne i dalece niedoskonałe, gdyby choć pobieżnie nie zajęło się euchologią, czyli modlitewną tradycją Kościoła i nie podjęło próby wyznaczenia wspólnego genotypu wszystkich chrześcijańskich liturgii w oparciu o wypracowane przez sam Kościół fundamenty.

\subsection{Lex credendi ukryte w lex orandi}

Wspólne dziedzictwo epoki patrystycznej całego Kościoła ukazuje nam, że dla Ojców liturgia była pierwszym miejscem ekspresji wiary oraz źródłem, z którego ta wiara Kościoła wypływała. Jak zauważył Cesare Giraudo „Ojcowie najpierw się modlą, a potem wierzą, modlą się, by móc wierzyć, modlą się, by nauczyć się, jak i w co należy wierzyć" ${ }^{34}$. Ta przeżywana i pobudzana na modlitwie wiara była i do dziś jest cechą wspólną całego chrześcijaństwa i najgłębiej wpisuje się we wspólny genotyp wszystkich tradycji. Bez względu bowiem na szerokość geograficzną i przynależność kulturową paradygmat płynący z ukrytego w lex orandi depozytu wiary jawi się jako wspólne dziedzictwo i bogactwo wszystkich wierzących.

Wskazując na wspólny genotyp euchologijny wszystkich wspólnot chrześcijańskich, jako pierwszy element należy wyznaczyć modlitwę, która dana została Kościołowi przez samego Pana (Mt 6,9-13; por. Łk 11,1-4). To ta modlitwa stanowi pierwsze słowa Pisma Świętego, których wszyscy chrześcijanie uczą się jako

33 Na temat różnorodności w kwestii użycia chleba do celebracji eucharystycznej zob. M. NiN, Pane, w: DEOC, s. 578. s. 16.

34 C. Giraudo, In unum corpus. Trattato mistagogico sull'eucaristia, Cinisello Balsamo 2001, 
dzieci i które towarzyszą im do ostatniego tchnienia ${ }^{35}$. Ta krótka modlitwa, będąca dla chrześcijan modlitwą par excellence, jednakowo przez wszystkie wspólnoty uznawana jest za wyjątkową i streszczającą w sobie całe spektrum próśb i potrzeb Kościoła $^{36}$. Katechizm Kościoła Katolickiego podkreśla istotne znaczenie tej najważniejszej modlitwy we wszystkich tradycjach liturgicznych. Przypomina, że pierwsze wspólnoty modliły się słowami „Ojcze nasz” trzy razy dziennie w miejsce żydowskiej tradycji odmawiania osiemnastu błogosławieństw (Szemone esre brachot), a wszystkie tradycje liturgiczne włączyły ją jako integralną część liturgii godzin oraz celebracji sakramentalnych (por. KKK 2767-2768). Zatem z całą pewnością jest ona podstawowym euchologijnym nośnikiem właściwego całemu chrześcijaństwu genotypu.

Wspólnym DNA euchologijnej tradycji Kościoła jest również komponowanie tekstów liturgicznych wyrażających podstawowe prawdy wiary. Niewątpliwie najznamienitszym przykładem takiej kompozycji jest uznawane przez wszystkie Kościoły i tradycje liturgiczne nicejsko-konstantynopolitańskie wyznanie wiary, które od starożytności stanowiło również najważniejszy probierz ortodoksyjności ${ }^{37}$. Chociaż jest to tekst dogmatyczny, na stałe wszedł on do użycia liturgicznego: dziś jego odmawianie w tradycjach orientalnych nie ogranicza się jedynie do celebracji eucharystycznej liturgii niedziel i uroczystości, ale inkorporuje Credo w strukturę każdej Boskiej liturgii oraz w modlitwę Jutrzni i Nieszporów.

\subsection{Struktura modlitwy eucharystycznej}

Kolejnym ogniwem genetycznego łańcucha liturgii Kościoła Wschodu i Zachodu potwierdzającym ich jedność są bez wątpienia rodzaje modlitw oraz ich generalna struktura. We wszystkich bowiem tradycjach liturgicznych spotykamy modlitwy uwielbienia, dziękczynienia, prośby czy modlitwy wstawiennicze. Ponadto w niemal każdej modlitwie liturgicznej zawierają się podobne elementy, które znane są jako: anakleza, będąca wezwaniem skierowanym do Boga, wymieniająca Jego różne przymioty oraz mająca na celu pobudzenie motywacji oraz ufności w modlącym się; anamneza, czyli przywołanie wielkich dzieł dokonanych przez Boga

35 Benedykt XVI, Rozważanie przed modlitwa Anioł Pański 25.07.2010, https://opoka.org.pl/biblioteka/W/WP/ benedykt_xvi/modlitwy/ap_25072010.html (10.01.2018).

36 Por. J. TheKkeparampiL, The Lord's Prayer According to Mar Jacob of Sarug ( $†$ 521), referat wygłoszony w ramach wykładów otwartych dla doktorantów WT UO (8.11.2017), przyjęty do publikacji w czasopiśmie „Liturgia Sacra”.

37 Zob. H. DenzINGER, Enchirodion symbolorum, definitionum et declarationum de rebus fidei et morum, Bologna 2003, s. 150. 
w historii zbawienia; epikleza, będąca szczególnym przyzywaniem imienia Bożego nad osobą bądź rzeczą; doksologia końcowa, czyli trynitarne uwielbienie Boga; aklamacja Amen, zawołanie stanowiące wyrażenie zgody i aprobatę dokonującego się działania ${ }^{38}$. Wszystkie te elementy są potwierdzeniem wspólnego genotypu chrześcijańskich liturgii.

Wśród modlitw Kościoła na szczególną uwagę zasługują anafory, czyli modlitwy eucharystyczne. Bazujące na najstarszych, często apokryficznych pismach, podania ukazują nam pierwotną strukturę modlitwy eucharystycznej, która mimo rozwoju zachowała istotne elementy w ukształtowanych już modlitwach eucharystycznych ${ }^{39}$. Cesare Giraudo zauważa, że w różnych tradycjach liturgicznych spotykamy anafory posiadające dynamikę anamnetyczną bądź epikletyczną, ale wszystkie one składają się z dziewięciu tożsamych elementów. Są to: prefacja wraz z dialogiem ją poprzedzającym, Sanctus, Post-Sanctus, pierwsza epikleza, słowa ustanowienia, anamneza, druga epikleza, modlitwy wstawiennicze i doksologia ${ }^{40}$. Chociaż układ tych komponentów może się różnić w zależności od tradycji, to jednak ich obecność we wszystkich liturgiach wskazuje na wspólny genotyp, o którym mowa w niniejszym studium. Ciekawym jest, że Giraudo w swoich dyskursach również posługuje się terminologią DNA, zwłaszcza w odniesieniu do syro-orientalnej anafory Addaia i Mariego. Jak wiadomo modlitwa ta nie zawiera słów ustanowienia wprost wszczepionych w swą strukturę, przez co w ciągu wieków była uznawana za ,anomalię” na gruncie euchologii eucharystycznej. W oparciu o nowe wytyczne Stolicy Apostolskiej ów rzymski jezuita dokonał szczegółowej analizy modlitwy i stwierdził, że słowa ustanowienia są obecne w modlitwie w zalążku, nie wprost. Jednakże nie wpływa to na ważność i ortodoksję anafory, gdyż to istotne odniesienie do wydarzeń z Wieczernika wpisane jest w DNA anafory, tj. przynależy do jej istoty i wewnętrznego ukierunkowania (sic!) ${ }^{41}$. Stąd zdaniem Giraudo, owo DNA jawi się jako rzeczywistość obiektywna, aczkolwiek nie do końca uchwytna: wyrażona poprzez intencję sprawowania Eucharystii w łączności z wydarzeniami paschalnymi oraz włączenie celebracji w strumień tradycji Kościoła. Innymi słowy można powiedzieć,

38 Modlitwa liturgiczna w: B. Nadolski, Leksykon liturgii, Poznań 2006, s. 950-951.

39 Zob. P.F. Bradshaw, M.E. Johnson, The Eucharistic Liturgies. Their evolution and interpretation, Collegeville 2012, s. 36-44.

40 Zob. C. Giraudo, In unum corpus, s. 265.

${ }^{41}$ C. GiRAudo, La genesi anaforica del racconto istituzionale alla luce dell'anafora di Addai e Mari: tra la storia delle forme e liturgia comparata, w: TENŻE (red.), The Anaphoral Genesis of the Institution Narrative in Light of the Anaphora of Addai e Mari. Acts of the International Liturgy Congress. Rome 25-26 October 2011, Roma 2013, s. 451. Por. TENŻE, L'anafora si Addai e Mari: banco di prova per la sistematica dell'eucaristia, w: tamże, s. 209-234. 
że chodzi tu o ponadwerbalne i w pewnym sensie metafizyczne uobecnienie, dla którego nie istnieją ramy czasowe. Wydaje się, że takie rozumienie liturgii jest wspólne dla całego Kościoła, stąd i ono jest płaszczyzną spotkania i przestrzenią wspólnego genotypu liturgii Kościoła na Wschodzie i Zachodzie.

\section{Zakończenie}

Liturgia Kościoła w każdej z tradycji liturgicznych posiada własne cechy charakterystyczne i własny koloryt wynikający z różnego rozłożenia akcentów teologicznych i celebracyjnych. Jednakże w swej istocie jest to jedna i ta sama liturgia jednego Kościoła, zdeterminowana przez najbardziej intymny genotyp zaszczepiony w niej u jej zarania. Można tu sparafrazować słynne zdanie Karla Bartha, który w odniesieniu do dialogu ekumenicznego miał powiedzieć: ,wierzymy inaczej, ale przecież nie w Innego". Na płaszczyźnie liturgicznej jako Kościół sprawujemy liturgię inaczej, ale nie inną. jest to bowiem ta sama liturgia, posiadająca to samo DNA, różniąca się jedynie zewnętrznymi formami wyrazu i podkreślająca różne aspekty teologiczne.

Wydaje się, że tak właśnie była rozumiana ukryta w tym DNA katolickość liturgii w pierwszych wiekach. Wymowny jest tu znany epizod z wizyty biskupa Polikarpa ze Smyrny w Rzymie w roku 154, w czasie której ów orientalny hierarcha celebrował liturgię w zastępstwie papieża Aniceta, nie powodując jakiegokolwiek zamieszania czy poruszenia ${ }^{42}$. Tak zresztą powinna chyba wyglądać pojednana różnorodność jednego Kościoła. Świadomość wspólnego DNA może bowiem ułatwić zrozumienie tego, o czym pisał Józef Ratzinger: „Liturgia chrześcijańska nie jest nigdy działaniem określonej grupy, określonego środowiska lub określonego Kościoła lokalnego. [...] Chrystus chce zjednoczyć ludzkość i doprowadzić do tego, że będzie istniał jeden Kościół, jedno zgromadzenie Boże wszystkich ludzi" ${ }^{43}$. Jedno zgromadzenie oparte na tym samym dziedzictwie.

Oczywiście świadomość wspólnego genotypu nie może prowadzić do odcinania się od własnych korzeni. Trzeba uważać, by nie ulec zbytniemu romantyzmowi, który mógłby poważnie zagrozić stosunkowi konkretnego człowieka do własnej tradycji liturgicznej. Przestrzegał przed tym Robert Taft w jednym ze swoich artykułów, gdy uwrażliwiał, aby nie szukać bogactw poza własną tradycją, by nie rozglądać się na zewnątrz za tym, co już mamy we własnej szafie. Odnalezienie

${ }^{42}$ Por. J.A. Jungmann, Liturgia Kościoła pierwotnego, s. 315.

43 J. Ratzinger, Duch liturgii, Poznań 2002, s. 46. 
wspólnego DNA liturgii i zestawienie go z tym, co wykształciło się w łonie każdej z tradycji powinno wzbudzić szacunek wobec dynamiki liturgii w jej konkretnym i partykularnym kontekście. Takie podejście wydaje się niezwykle aktualne chociażby w odniesieniu do liturgii rzymskiej, gdzie widzimy coraz więcej pietyzmu wobec tzw. liturgii trydenckiej kosztem deprecjonowania liturgii zreformowanej po Soborze Watykańskim II. Tymczasem, jak mówi Taft, Zachód nie musi zwracać się gdziekolwiek: ani na Wschód, ani do średniowiecza czy Trydentu. Zachód musi powrócić do swoich korzeni, wszak chrześcijaństwo łacińskie jest tak samo apostolskie (na co wskazuje powyższe studium), tak samo starożytne, tradycyjne, patrystyczne, duchowe i monastyczne jak wszystkie inne czcigodne tradycje Kościoła. Owszem, Wschód z Zachodem wzajemnie się potrzebują, powinny uczyć się od siebie i siebie nawzajem. Jednak w tym wszystkim, doceniając wspólne DNA, wszyscy chrześcijanie powinni być dumni z własnej tradycji, integralnej części mozaiki całego Kościoła.

\section{Streszczenie}

Chociaż liturgia Kościoła w każdej z tradycji liturgicznych posiada własne cechy charakterystyczne będące wynikiem odrębnej ewolucji oraz różnego rozłożenia akcentów teologicznych i celebracyjnych, to w swojej istocie jest jedną i tą samą liturgią jednego Kościoła. W punkcie wyjścia niniejszego studium ukazano elementy różniące poszczególne ryty w Kościele, a następnie te, które składają się na wspólny genotyp wszystkich wspólnot. Wśród nich szczególną uwagę zwrócono na liturgię żydowską, głoszenie kerygmatu, życie sakramentalne, wspólną geografię początków, euchologię wraz z ukrytym w niej lex orandi oraz strukturę Modlitwy Eucharystycznej.

Slowa kluczowe: liturgia, euchologia, genotyp, DNA, rodziny liturgiczne, liturgia żydowska, historia liturgii.

\section{The Common DNA of the Eastern and Western Liturgy}

Abstract

Even if each liturgy of the different liturgical traditions has its own characteristics which are results of the different evolution and different theological approaches, in its lessens it still remains the one and same liturgy of the Church. Before describing the common DNA of the Christian 
liturgy, as the starting point of this paper, we showed a couple of elements which differ the rites of the Church. In the main part of the study the elements containing the common liturgical DNA were presented. Among them we pointed: the Jewish liturgy, proclamation of the Kerygma, sacramental life, the common proto-geography, euchology which lex orandi and the structure of the Eucharistic Prayer.

Keywords: liturgy, euchology, genotype, DNA, liturgical families, Jewish liturgy, history of the liturgy.

\section{Bibliografia}

BeCKwith R.T., The Jewish Background to Christian Worship, w: Ch. Jones I IN. (red.), The Study of Liturgy, New York 1992, s. 68-80.

Benedykt XVI, Rozważanie przed modlitwa Aniot Pański 25.07.2010, https:// opoka.org.pl/biblioteka/W/WP/benedykt_xvi/modlitwy/ap_25072010.html (10.01.2018).

Benedykt XVI, Verbum Domini, Città del Vaticano 2010.

Bouyer L., Architettura e liturgia, Magnano 2007.

BOUyer L., Eucaristia. Teologia e spiritualità della preghiera eucaristica, Leumann 1983.

Bradshaw P.F., Johnson M.E., The Eucharistic Liturgies. Their evolution and interpretation, Collegeville 2012.

Brock S., The Holy Spirit in the Syrian baptismal tradition, Kottayam 1998.

CRichton J.D., A Theology of Worship, w: CH. Jones I IN. (red.), The Study of Liturgy, s. 3-31.

CZerski J.M., Liturgie Kościołów Wschodnich, Opole 2009.

Dalmais I.-H., Liturgies d'Orient. Rites et symboles, Paris 1980.

DenzInger H., Enchirodion symbolorum, definitionum et declarationum de rebus fidei et morum, Bologna 2003.

Farrugia E.G., Praestantia ritus latini, w: tenże (red.), Dizionario enciclopedico dell'Oriente Cristiano, Roma 2000, s. 611-612.

Genetic Science Learning Center, What are DNA and Genes?, http://learn.genetics.utah.edu/content/basics/dna (29.10.2017).

Giraudo C., In unum corpus. Trattato mistagogico sull'eucaristia, Cinisello Balsamo 2001. 
GIRAUdo C., L'anafora si Addai e Mari: banco di prova per la sistematica dell'eucaristia, w: TENŻE (red.), The Anaphoral Genesis of the Institution Narrative in Light of the Anaphora of Addai e Mari. Acts of the International Liturgy Congress. Rome 25-26 October 2011, Roma 2013, s. 209-234.

GIRAUDO C., La genesi anaforica del racconto istituzionale alla luce dell'anafora di Addai e Mari: tra la storia delle forme e liturgia comparata, w: TENŻE (red.), The Anaphoral Genesis of the Institution Narrative in Light of the Anaphora of Addai e Mari. Acts of the International Liturgy Congress. Rome 25-26 October 2011, Roma 2013, s. 425-454.

Hage W., Syriac Christianity in the East, Kottayam 1997.

JAN PAwEŁ II, Ut unum sint, Città del Vaticano 1995.

Jenkins P., The Lost History of Christianity, New York 2008.

Jungmann J.A., Liturgia Kościoła pierwotnego do czasów Grzegorza Wielkiego, thum. T. Lubowiecka, Tyniec 2013.

Kunzler M., Liturgia Kościoła, Poznań 1999.

Martimort A.G., Struttura e leggi della celebrazione liturgica, w: tenże (red.), La Chiesa in preghiera. Introduzione alla Liturgia, t. 1, Brescia 2009, s. 109255.

Modlitwa liturgiczna w: B. NADOLSKI, Leksykon liturgii, Poznań 2006, s. 950-951. Nadolski B., Wprowadzenie do liturgii, Kraków 2004.

Nin M., Pane, w: E.G. Farrugia, Dizionario enciclopedico dell'Oriente Cristiano, Roma 2000, s. 578.

PAProcki H., Misterium Eucharystii, Kraków 2010.

Potoczny M., Praxis i teologia chrztu w liturgicznej tradycji syro-orientalnej, „Studia Łódzkie” 26 (2017) 2, s. 135-149.

Pотосzny M., Rodziny liturgiczne chrześcijańskiego Wschodu - panorama, „Teologia i człowiek" 25 (2014) 1, s. 165-185.

Potoczny M., Słowo Boże w liturgii eucharystycznej Kościołów syryjskich, „Studia Liturgiczne" 13 (2017), s. 155-171.

Ratzinger J., Duch liturgii, Poznań 2002.

Righetti M., Storia liturgica, v. 4, I sacramenti - i sacramentali, Milano 2014.

Sobór Watykański II, Dekret o kościołach wschodnich katolickich „Orientalium Ecclesiarum”, w: SoBór WaTYKAŃSKi II, Konstytucje, dekrety, deklaracje, Poznań 2002.

Srawley J.H. (red.), The Epistles of St. Ignatius Bishop of Antioch, Brighton 1910. Thekkeparampil J., The Lord's Prayer According to Mar Jacob of Sarug († 521), referat wygłoszony w ramach wykładów otwartych dla doktorantów WT UO (8.11.2017), przyjęty do publikacji w czasopiśmie „Liturgia Sacra”. 
Mateusz Potoczny, doktor kościelnych nauk wschodnich (PIO Rzym), prezbiter diecezji opolskiej, birytualista. Specjalizuje się w liturgiach Kościołów syryjskich (studia: SEERI, Kottayam, Kerala - Indie). Adiunkt w Instytucie Liturgiki, Sztuki i Muzyki Sakralnej Wydziału Teologicznego Uniwersytetu Opolskiego. E-mail: mpotoczny@uni.opole.pl. 